\title{
Modern brackish bryostromatolites ("bryoliths") from Zeeland (Netherlands)
}

\author{
G. William M. Harrison ${ }^{1,2}$ (D) Anna Lene Claussen ${ }^{2} \cdot$ Christian Schulbert $^{2} \cdot$ Axel Munnecke $^{2}$
}

Received: 13 May 2020 / Revised: 16 July 2020 / Accepted: 3 March 2021 / Published online: 17 June 2021

(C) The Author(s) 2021

\begin{abstract}
Bryostromatolites are found in stressed environments from the Paleozoic to the Recent. They are formed by alternating layers of bryozoans and microbes. This study investigates recent bryostromatolites in brackish ponds in the Netherlands to better understand ancient analogues and the environments which hosted them. They formed a fringing reef at the site Ronde Weel and a barrier reef at Kaaskenswater. The ponds had low biodiversity with only one bivalve species, two gastropod species, one ostracod species, and three diatom species comprising most of the easily fossilizable taxa; one isopod species, one decapod species, and two polychaete species were also present. Observations of microbial layers and cementation practices indicate that an alternation of bryozoan-favouring conditions and microbe-favouring conditions is essential to forming bryostromatolites. The collected bryostromatolites only had tiny living bryozoan patches. Water tests confirmed a brackish environment but with enriched arsenic and titanium concentrations and periodic euxinia. The extreme environment explains the lack of biodiversity and may provide information about the environments in which past bryostromatolites formed.
\end{abstract}

Keywords Bryozoan $\cdot$ Bryostromatolite $\cdot$ Reef

\section{Introduction}

Bryostromatolites

Bryostromatolites are a relatively rare habitat formed by stationary alternating layers of encrusting bryozoans and microbes (Palinska et al. 1999). They frequently have a characteristic cauliflower shape on their surface. Bryostromatolites are first found in the Late Ordovician (Kröger et al. 2017) but are better described from the Silurian and Miocene (Goncharova and

G. William M. Harrison

william.harrison@naturalis.nl

Anna Lene Claussen

anna.lene.claussen@fau.de

Christian Schulbert

christian.schulbert@fau.de

Axel Munnecke

axel.munnecke@fau.de

1 Naturalis Biodiversity Center, PO Box 9517, 2300

RA Leiden, The Netherlands

2 GeoZentrum Nordbayern, Friedrich Alexander University Erlangen-Nuremberg, Loewenichstr. 28, 91054 Erlangen, Germany
Rostovtseva 2009; Saint Martin and Pestrea 1999; Ernst et al. 2015; Brandano et al. 2017; Sladkovskaya 2017; Claussen et al. 2022). The Miocene bryostromatolites are only found in the Tethys and Paratethys around the time of the Messinian salinity crisis (Goncharova and Rostovtseva 2009; Saint Martin and Saint Martin 2015), which suggests that stressed environments assist the formation of bryostromatolites even during ancient times. While these bryostromatolites are also bryoliths because they are formed by somewhat detectable units that are roughly spheroidal in shape, this paper follows Palinska et al. (1999) in referring to them as bryostromatolites to avoid confusion with the rolling bryozoan multilayered crusts found elsewhere in the world and more commonly called bryoliths (Moissette et al. 2010; Tâmega et al. 2019).

Recent bryostromatolites have also been reported from Australia (Palinska et al. 1999) and the Netherlands (Bijma and Boekschoten, 1985). Bijma and Boekschoten (1985) provided a detailed description of the grow form, including noting the typical "cauliflower morphology" of the bryostromatolite. However, they did not employ SEM or thin sectioning techniques, preferring hand sample analyses. Indeed, they concluded that the stromatolites were calcified based on the hardness of the stromatolite as observed by touching it. Palinska et al. (1999) conducted thorough in vivo analyses of 
the microbes but did not give a detailed description of the overall structure of the bryostromatolite. More work is needed to analyse the actual structure of bryostromatolites. Not only will this work give new insights on an important feature in some modern ecosystems, it will allow us to make inferences about past bryostromatolites based on knowledge that can only be obtained from the modern ones.

\section{Bryozoans}

Skeletonized bryozoans originate in the Ordovician (Taylor and Ernst 2004). Bryozoans are colonial filter feeders that are found throughout modern and ancient bodies of water. While the Paleozoic clades were prolific reef builders (Ernst 2019), modern bryozoans still form minor components of modern tropical and shallow reefal carbonates (Ernst 2019), living in any sheltered location with enough current and nutrients for filter feeding (Hayward 1979; Rosso and Geronimo 1998) or in cold water settings (Bone and James 1993; Andruleit et al. 1996; Clarke et al. 1996; Bader 2001). Their broad resistance to toxins, particularly metals (Piola and Johnston 2006; Moran et al. 2010; McKenzie et al. 2012a, b), enables them to inhabit high nutrient environments that are closed to competitors and predators due to human pollutions, such as sewers, dock areas, and ship hulls painted with anti-fouling paints (McKenzie et al. 2012a).

\section{Cyanobacteria}

Cyanobacteria are another ancient clade, dating back to the Archean (Chafetz and Buczynski 1992; Hofmann 2000; Shestakov and Karbysheva 2017). Like bryozoans, some cyanobacteria produce a mineralized skeleton. However, unlike bryozoans whose skeletons are controlled internally, cyanobacteria create their skeletons in the water outside their cells, leaving the process extremely vulnerable to changes in water chemistry (Merz 1992). Cyanobacteria have declined in importance starting in the Proterozoic. The evolution of bioturbating organisms in the Cambrian destroyed unlithified matgrounds while grazers annihilated the stromatolites, reducing cyanobacteria to small colonies in cryptic habitats and larger formations in extreme environments that exclude grazers and bioturbators (Stal 2012). The climate in the Netherlands is temperate, which is rare but not unheard-of for stromatolites (Proemse et al. 2017). Cyanobacteria can survive in extreme conditions which kill most single-celled and multi-cellular organisms, allowing them to survive in places like Shark Bay, Australia (Burns et al. 2004). Cyanobacteria can also survive anoxia by using the sulphide from hydrogen sulphide as an electron donor in photosynthesis instead of water (Cohen et al. 1975).
Aims

This paper aims to elucidate the unique microhabitat provided by bryostromatolites. Understanding both environment and the macro- and micro-structures found in bryostromatolites from the Netherlands are necessary for a complete comprehension of the system, which will help palaeontologists understand the mechanisms and environmental conditions that lead to the formation of bryostromatolites in ancient environments.

\section{Materials and methods}

Ronde Weel and Kaaskenswater in the Zeeland region of the Netherlands were selected for this study (Fig. 1). Both were described by Bijma and Boekschoten (1985) and were chosen for resampling in this study. Bijma and Boekschoten (1985) collected bryostromatolites at multiple ponds in the Netherlands. These reefs were all found in brackish ponds (Bijma and Boekschoten 1985). While they made many claims about the water quality in the ponds, such as stating that there were no connections to the oceans, Bijma and Boekschoten (1985) did not show any analyses to back up their claims. However, Ronde Weel is known to have periodic euxinia (Monumentenstad 2018). The sites were visited several hours apart on April 2, 2019. All samples in this study were taken in 1 day. The locality of Diepe Gat is used as reference for identification of the bryozoan species due to the living bryozoans being easier to identify (Fig. 2); it did not contain bryostromatolites.

Both ponds are artificial. Ronde Weel and Kaaskenswater were formed on October 3, 1575, when the Spanish breeched the Dutch dykes (Monumentenstad 2018). Records of "growing stones" in these waters, which are called "kaaskens" in Dutch (little cheese), date back to 1673 (Bijma and Boekschoten 1985). All the bryozoans were identified as Einhornia crustulenta (Pallas, 1766), the same species found previously at those locations (Bijma and Boekschoten 1985). According to Nikulina (2007), Einhornia can be identified by the uni- to multiserial growth, the presence of calcified opercula (Fig. 2c) and proximedial spines (Fig. 2d). All this specifications can be recognised in the specimens that were forming the bryostromatolites. As reason to this, they were identified as Einhornia crustulenta (Pallas, 1766).

Bryostromatolite samples, including a whole bryostromatolite pried out of a reef, were collected. Small samples were preserved in alcohol while larger samples were dried. Both a Zeiss AxioZoom.v16 binocular with Axiocam 506 colour and a Zeiss Imager.M2m microscope with Axiocam MRc5 were used with the Zen core v2.6 program to create high-resolution photographs of the smaller bryostromatolites before other analyses were conducted. Larger samples were photographed with a Nikon D750 camera. Most samples were dried before photography while others were photographed in alcohol. Some 


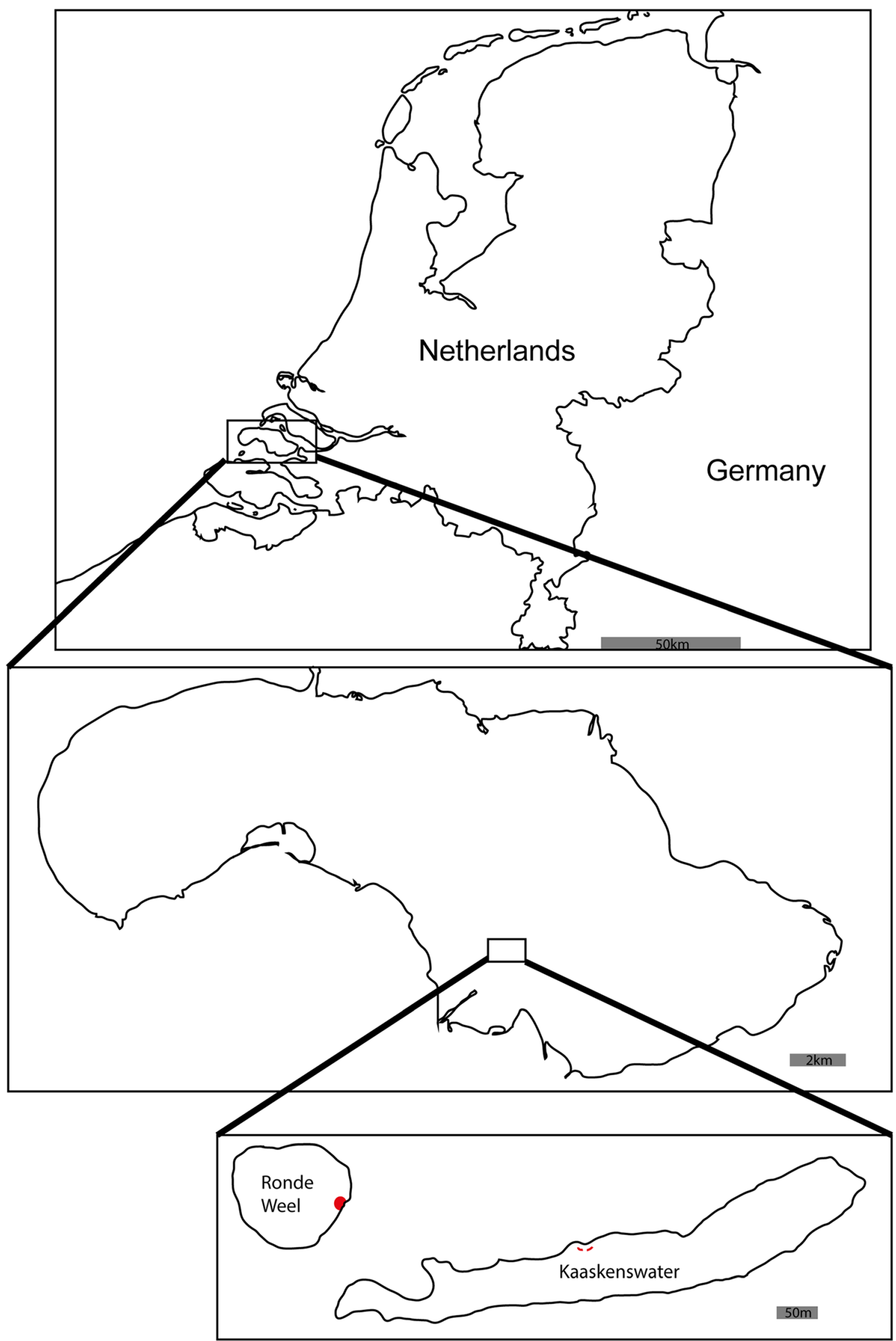

Fig. 1 Map of the field locations at Ronde Weel and Kaaskenswater in the context of the Netherlands. Sampling sites are marked in red 

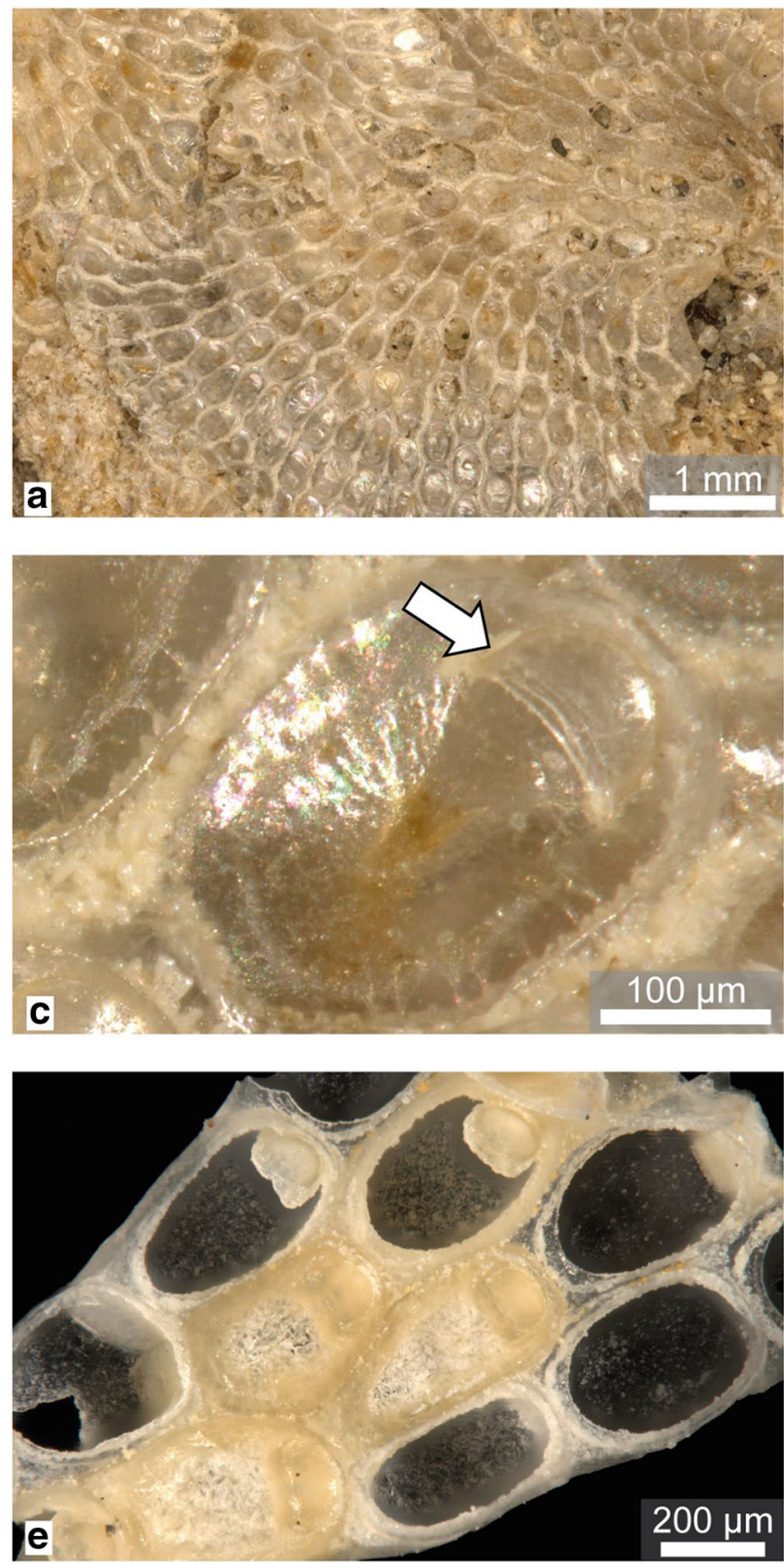

Fig. 2 Einhornia crustulenta from the nearby Diepe Gat showing the characteristic a-b uni- to multiserial growth, $\mathbf{c}$ the presence of calcified opercula, and d proximedial spines. Specimens from Diepe Gat were figured because specimens from Ronde Weel and Kaaskenswater mostly contained cements. Bryozoans at Diepe Gat did not form

samples were thin sectioned after being soaked in hydrogen peroxide to remove sediment and organics while others were thin sectioned without treatment to preserve sediments and organics; these samples were analysed under the microscope cameras. Small samples were mounted and imaged under a Tescan VEGA 2 scanning electron microscope with VegaTC imaging software.
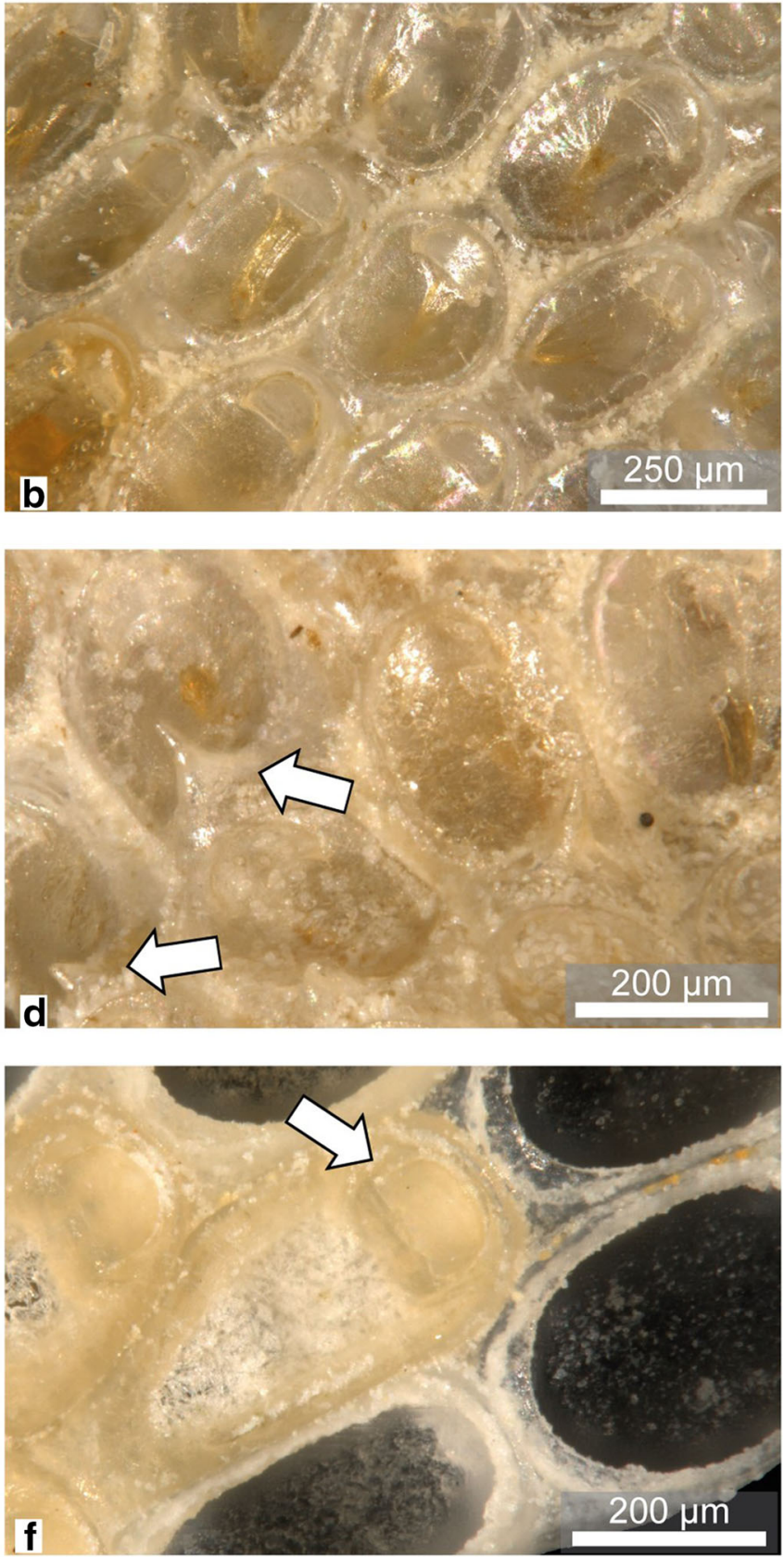

bryostromatolites; future work hopes to discover why. e-f Specimens from Ronde Weel; while water conditions at Ronde Weel resulted in somewhat fouled specimens, the opercula and proximedial spines are still clearly visible

One bryostromatolite fragment from Kaaskenswater was selected for micro-CT analysis (microCT phoenix $\mathrm{v} \mid$ tome|x research edition with the software VGStudio Max3.0; tube voltage of $120 \mathrm{kV}$, a tube current of $350 \mu \mathrm{A}$, Filter of $0.5 \mathrm{~mm}$ Sn and 1500 projections). After scanning, voids were separated out from bryozoans and muds. A closing algorithm was run to close all openings to the outside. Volumes for all 
voids and matter were calculated. Sections were sampled with few openings to the outside to avoid edge effects of the algorithm's pore-closing protocols.

One water sample was taken at each pond. They were stored in PET bottles in cool, dark conditions for 2 days before being given to the hydrogeology lab at FAU and analysed with ICP-MS. The storage conditions were not ideal, so only overall element concentrations and stable ions were analysed.

\section{Results}

The main focus of this project was the bryostromatolite reefs found in Ronde Weel and Kaaskenswater. The reefs in Kaaskenswater were barrier reefs in morphology (Fig. 3a). There was a space of $6 \mathrm{~m}$ between the shore and the reefs at the westernmost point with little variation at other locations. Around 1 to $2 \mathrm{~m}$ of this space was composed of reeds, which formed a platform close to the shore. Between the reeds and the reef were waters up to $1 \mathrm{~m}$ in depth. Beneath these waters was a soft, sticky mud that smelled strongly of hydrogen sulphide when disturbed. A debris talus stabilized the mud near to the reef. The reef stretched for around $15 \mathrm{~m}$ in an east-west direction, roughly following shoreline morphology. The eastern and western most portions consisted of a central patch that was exposed above the water surface with submerged sections to the east and west. These were connected by a fully submerged centre. The reef dropped off sharply to the north and south and always had a depressed groove in the centre (Fig. $3 \mathrm{c}$ ). The reef rose approximately $1 \mathrm{~m}$ above the lake bottom. Small cryptic patches of bryozoans were unfouled at the time of collection, but the majority of the reef surface was living microbes covering dead bryozoans.

The Ronde Weel study site was a fringing bryostromatolite reef (Fig. 3b) in the east of the pond. It is visible on google maps as a light spot. The reef was entirely in less than $30 \mathrm{~cm}$ water depth in April of 2019 with the tops of some reefs breaching the surface. It stretched $1.5 \mathrm{~m}$ away from the shore and ran for $4.5 \mathrm{~m}$. The reef pinched out towards a water intake to the north and had reeds to south. A second portion is $13 \mathrm{~m}$ long with an additional $4 \mathrm{~m}$ of smaller, unattached bryostromatolites to the south of it. Its size varied from $2.5 \mathrm{~m}$ away from the shore at the southernmost part to $6.5 \mathrm{~m}$ at its greatest extent ( $9 \mathrm{~m}$ north of the southernmost point) and $4 \mathrm{~m}$ at the northernmost part. All reefs were covered in green microbes at the time of collection (Fig. 3d). Most bryozoans were heavily fouled but some small patches remained unfouled and likely alive until they were placed in alcohol or dried. Civilians approached the researchers at Ronde Weel and gave accounts of the pond smelling like cleaning chemicals or rotten eggs in the summer of 2018 .

Bryostromatolite reefs can be separated into individual bryostromatolites that grow together to form the reef (Fig. 3b). These bryostromatolites had a typical cauliflower morphology (Fig. 3c). However, bryostromatolites are full of mud between the bryozoan layers, with a thick green layer at the top (Fig. 5a). Unfouled bryozoans are rare and mostly found growing on the lower part of the side of bryostromatolites. Micro-CT scans of a cauliflower structure from Kaaskenswater revealed a complex 3-dimensional structure of higher and lower density layers of bryozoans (Fig. 4a-b). The investigated bryostromatolites had $61 \%$ porosity. Internal pores in bryozoans accounted for $0.2 \%$ of porosity (Fig. $4 \mathrm{e}$ ); around $5 \mathrm{~mm}^{3}$ of pore space was generated by micropores and $2400 \mathrm{~mm}^{3}$ was occupied by the main pore.

All bryozoans belong to Einhornia crustulenta (Pallas, 1766) (Bijma and Boekschoten 1985). This species occurs throughout the Northern Atlantic, Baltic, and Northern Seas in marine and brackish habitats (Nikulina 2007). Microbial mud occurred between the bryozoan layers to form a layercake of microbes and bryozoans overgrowing each other, known as a bryostromatolite (Fig. 5a). These cyanobacteria bloomed when specimens were cleaned with diluted $\mathrm{H}_{2} \mathrm{O}_{2}$ and turned the buckets bright green. In thin section, they had a thrombolytic texture of clotted strings and connected layers of bryozoans (Fig. 5b); this was also apparent under the SEM (Fig. 5c). Under the SEM, cyanobacteria formed both 3dimensional and flat strands (Fig. $5 \mathrm{c}-\mathrm{e}$ ). These strands were found on bryostromatolites that were not treated with hydrogen peroxide (Fig. 5c, e), bryostromatolites treated with hydrogen peroxide, and in the residue left behind after the hydrogen peroxide treatments (Fig. 5d). They bound the residues together (Fig. 5d), forming uncemented mats. These strands often fused to form flat microbial mats (Fig. 5c). Microbes grew on top of both bryozoans (Fig. 5c) and cements (Fig. 5e). Microbes and cements were observed overgrowing each other in very close proximity (Fig. 5e). The microbes were identified as cyanobacteria using the morphology of the strands (Komárek and Anagnostidis 2005). While Todd and Turner (1988) observed that the cheilostome bryozoans stayed alive after been overgrown by ascidians, we observed that the fouled bryozoan colonies had cements inside their skeletons, showing that they were dead (Fig. 5c).

The bryostromatolites were not just composed of bryozoans and structure forming cyanobacteria. They also contained other microbes, diatoms, and metazoans (Table 1). The microfauna included both peloidal microbes (Fig. 5a), boring microbes (Fig. 6b), and three species of diatoms (Fig. 6c-f). The boring microbes had a distinctly cyanobacterial morphology in thin section (Stanier and Cohen-Bazire 1977) and cyanobacteria are known to bore into shells (Pantazidou et al. 2006). One diatom species, identified as Halamphora sp. 1, sometimes formed meadows (Fig. 6c) on top of cyanobacteria mats. One bivalve species was seen in hand sample (Fig. 6g), and at least two gastropod species were present. Decapods and isopods were found rarely as were two different types of 

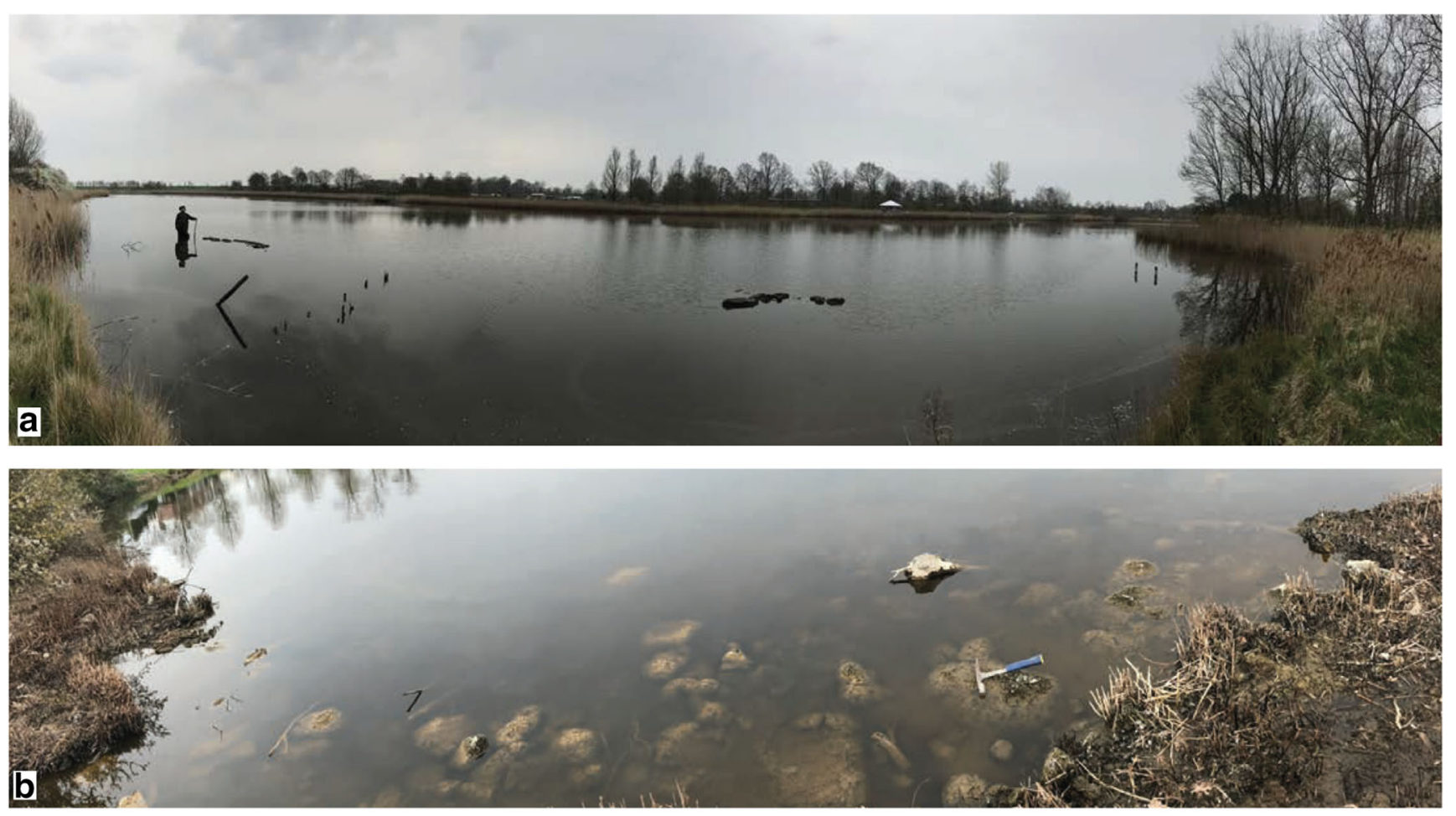

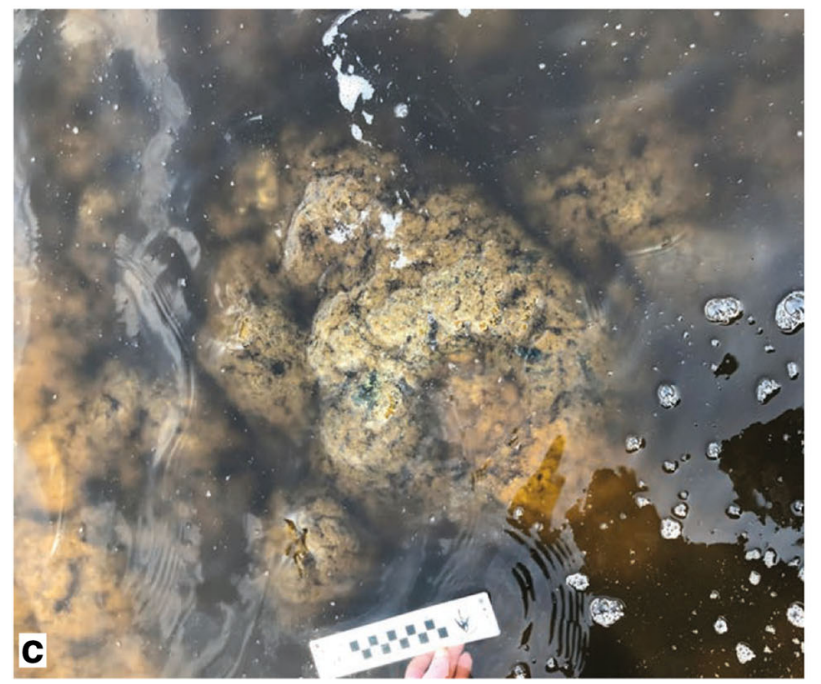

Fig. 3 Bryostromatolite reefs at Kaaskenswater and Ronde Weel. The bryostromatolites formed $\mathbf{a}$ a barrier reef at Kaaskenswater and $\mathbf{b}$ a fringing reef at Ronde Weel. The reef manifested as $\mathbf{c}$ a large patch of

polychaete jaws and at least one species of ostracod. Insect larvae were also observed. No freshwater taxa were found; all determined species were brackish and/or marines, including E. crustulenta (Nikulina, 2007).

The water samples were analysed for salinity and various ion concentrations (Table 2). Ions which are above standard levels for freshwater or marine systems are reported below (see supplementary data for all values). Additionally, the characteristic smell of hydrogen sulphide was detected in the mud at all sample localities.

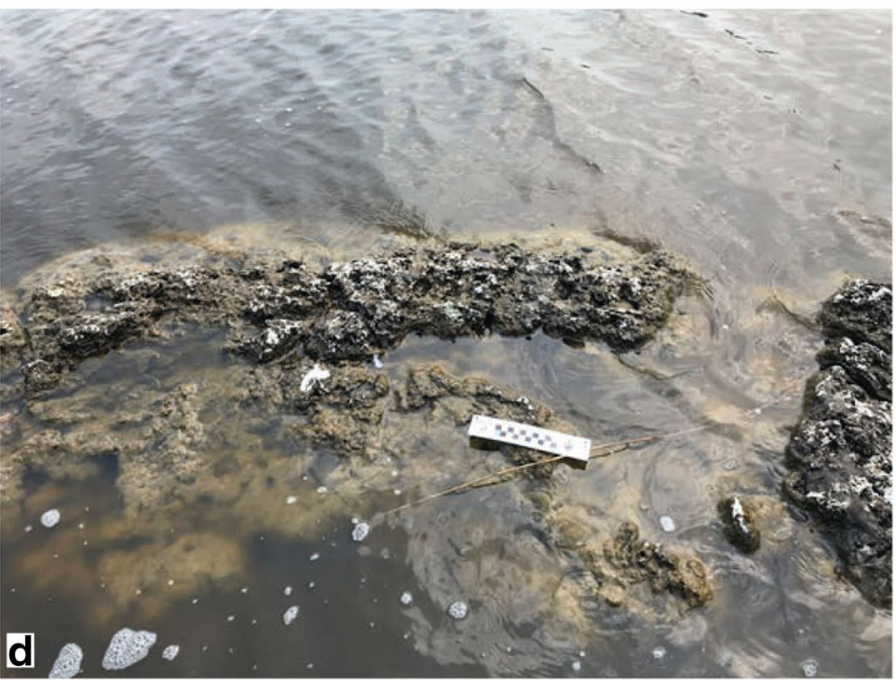

bryostromatolites with no particular orientation at Ronde Weel and $\mathbf{d}$ a long and narrow chain of bryostromatolites with a depression in the middle at Kaaskenswater

\section{Discussion}

Water quality

The water quality is a clear stressor. The salinity is brackish. No obvious connections to the ocean existed for all sites but the Netherlands is too humid for a saline pond to form by evaporation. All sites were within $2 \mathrm{~km}$ of the ocean, so an underground connection is not impossible although we have no other evidence for this. An underground connection would 

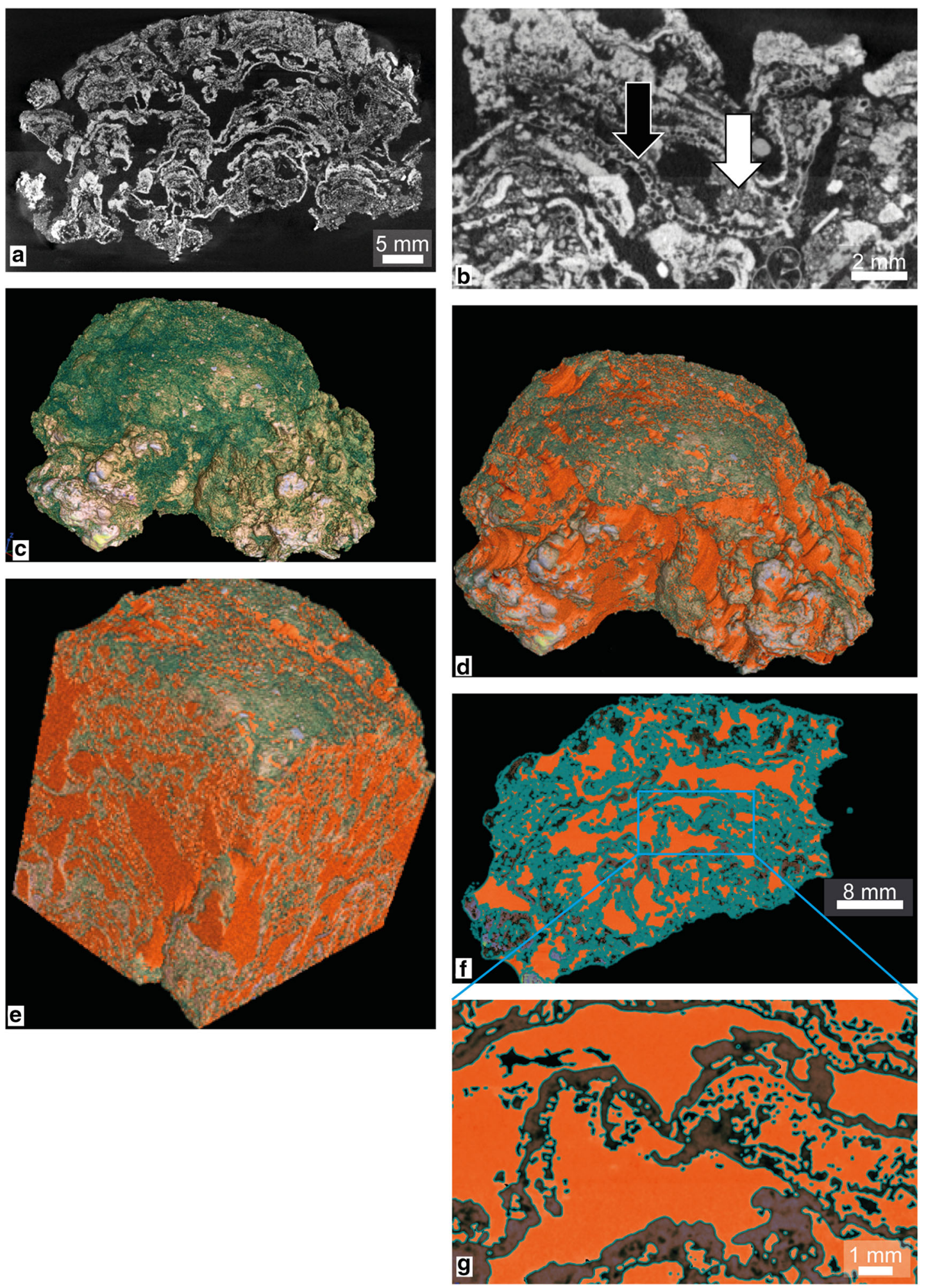

Fig. 4 CT scans of a fragment of a bryostromatolite. a This CT image shows the layercake structure of the bryostromatolite. b Close up image showing bryozoans (black arrow) and cements (white arrow). c The 3D CT image of the bryostromatolite. d A 3D CT image with the bryostromatolite in green and the voids in red. Note that the poreclosing algorithm smooths the surface and adds extra pore volume, espe-

to avoid exaggerating the estimated pore volume due to artefacts from the closing algorithm. This was used for counting the percent pore volume. $\mathbf{f}$ A CT image showing the bryostromatolite in green and the voids in red. The pore space appears relatively small. $\mathbf{g}$ A zoomed in image on a portion of the former one. It is now clear that pore space dominates cially on the side. $\mathbf{e}$ A subset taken from the centre of the bryostromatolite 

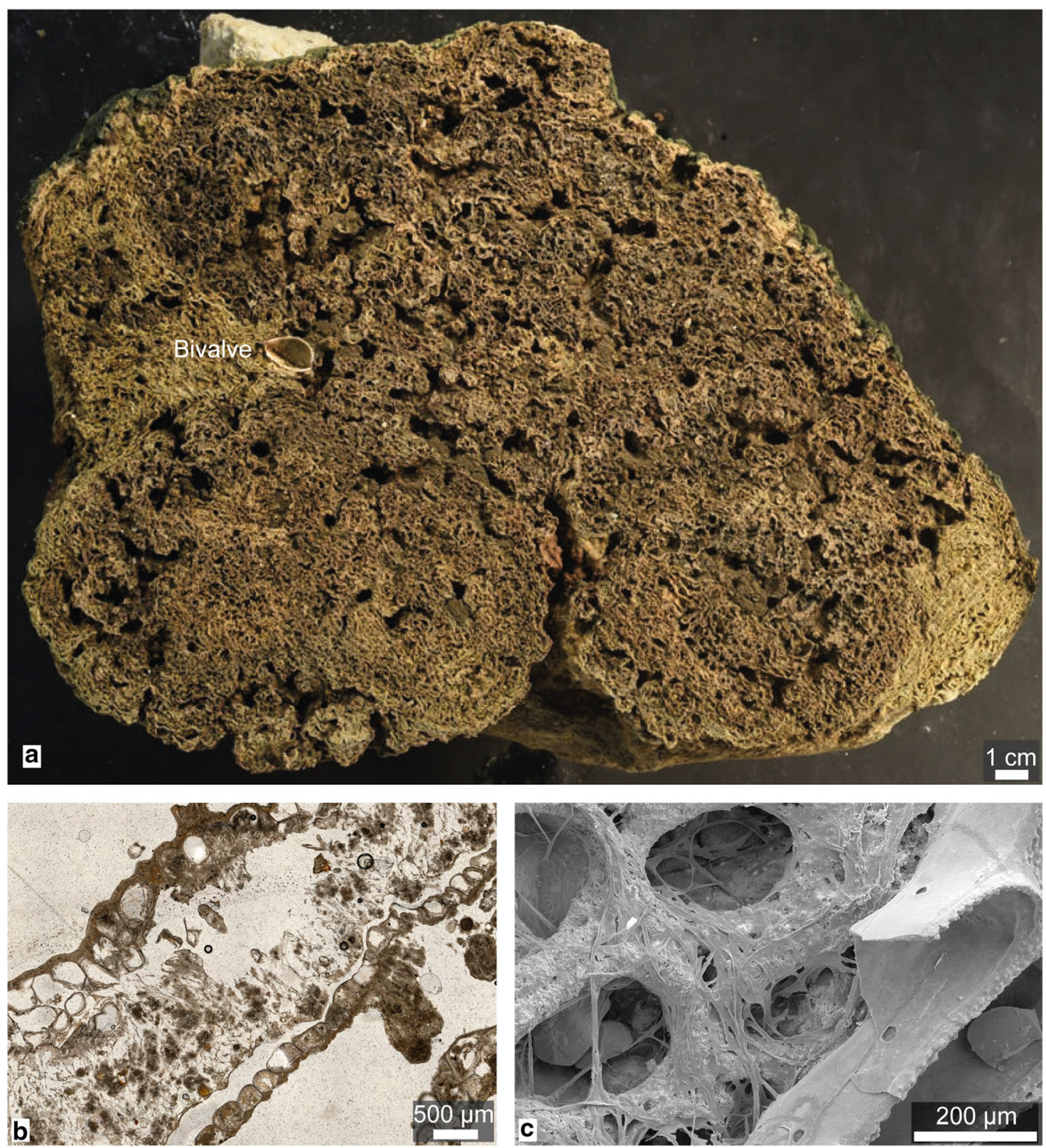

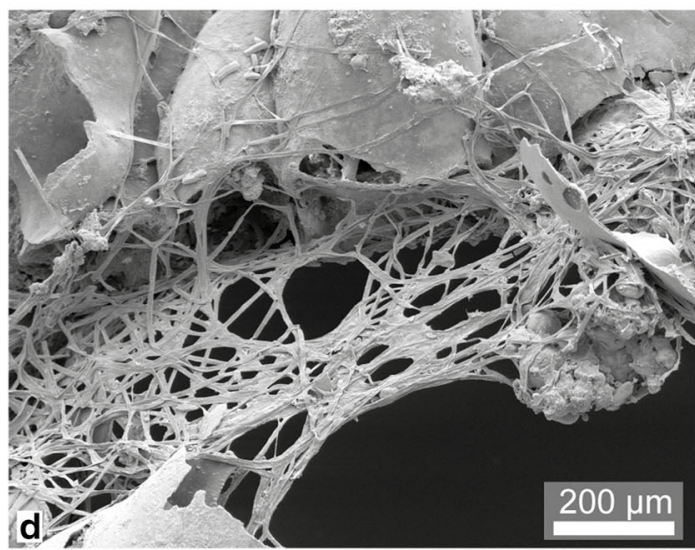

Fig. 5 Bryozoans and structure-forming microbes. a Overview picture of a bryostromatolite. $\mathbf{b}$ Thin section showing thrombolytic texture of microbes connecting bryozoans. c SEM image of microbes connecting two

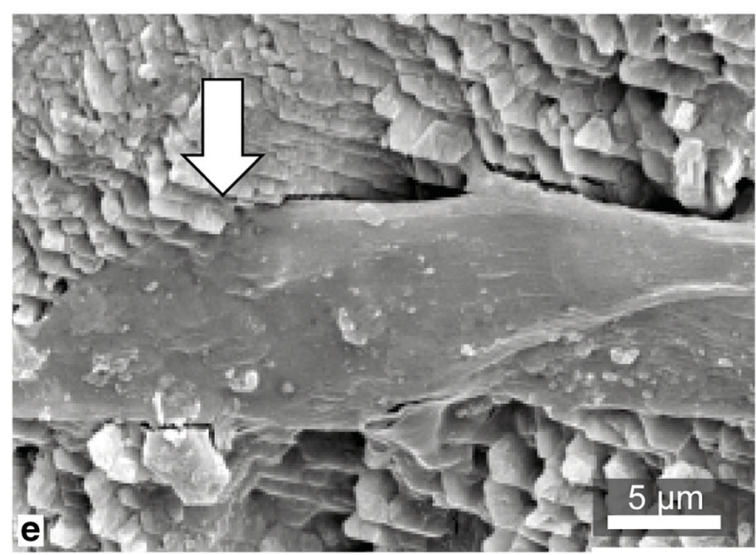

layers of bryozoans. d SEM image of microbes holding sediments together in hydrogen peroxide residue. e Close up image of a microbial thread growing on and being overgrown by cements (arrow) 
Table 1 Non-structure-forming taxa found in bryostromatolites (Costello et al. 2001; Hartley 1986)

\begin{tabular}{llll}
\hline Taxon & Higher affinities & Habitat preference & Occurrence in sample \\
\hline Isopod & Arthropoda & Unknown & Rare \\
Decapod & Arthropoda & Unknown & Rare \\
Polychaete sp. 1 & Polychaeta & $?$ & Rare \\
Polychaete sp. 1 & Polychaeta & $?$ & Rare \\
Cerastoderma sp. & Mollusca & Brackish-Marine & Common \\
Gastropod sp. 1 & Mollusca & Unknown & Common \\
Gastropod sp. 2 & Mollusca & Unknown & Common \\
Ostracod & Ostrocoda & Unknown & Rare \\
Halamphora sp. 1 & Diatom & Varied & Common \\
Halamphora sp. 2 & Diatom & Varied & Rare \\
Achantes pseudogroenlandica? & Diatom & Marine & Common \\
\hline
\end{tabular}

cause minor tidal changes in both water level and salinity as more saline water from the ground was brought into the pond at high tide and exited at low tide. The density difference in Ronde Weel and Kaaskenswater might cause stratification, with little mixing between the denser, saltier ocean water on the bottom and the lighter, fresher water on top.

Arsenic, titanium, and sulphate are above normal levels for even a polluted stream (Orians et al. 1990; Algeo et al. 2015; Rainbow 2018) and manganese is elevated at Ronde Weel (Rainbow 2018). The sulphate suggests euxinia as a second stressor. The sulphate at Ronde Weel is $3 \mathrm{x}-4 \mathrm{x}$ normal amounts, which support government reports of euxinia (Monumentenstad 2018). Kaaskenswater has $4 x-5 x$ the normal amounts of sulphate, suggesting that it is also periodically euxinic; this is supported by the strong smells of hydrogen sulphide in its mud.

The heavy metals represent another stressor. Arsenic is a well-known poison that affects all DNA-based life; it is $2 \mathrm{x}-6 \mathrm{x}$ normal unpolluted concentrations in this study area. Furthermore, titanium is extremely elevated in both ponds. The source of this titanium is unknown but titanium is a known carcinogen. Both these toxins likely excluded poison-sensitive taxa, leaving taxa such as bryozoans (Piola and Johnston 2006; Moran et al. 2010; McKenzie et al. 2012a, b). It is unsurprising that the cyanobacteria could survive these conditions since they were observed to thrive in hydrogen peroxide in the laboratory during this study.

Storage of water samples was problematic. The Hydro- \& Environmental Geology working group at Friedrich-AlexanderUniversity Erlangen-Nuremberg assisted us with water sample tests. Since the bottles were fully sealed, it is unlikely that total arsenic, manganese, or titanium levels changed significantly; while their charge and the compounds in which they were bonded may have shifted, this was not measured. Furthermore, sulphate requires relatively little preservation besides chilling so it should not have been affected (ISO, 2018; Shelton 1994). Therefore, these results should not have been biased by sample storage.
Bryostromatolite structure

CT scans demonstrated that the bryostromatolites were indeed layercakes with low density mud and microbes filling some spaces between denser bryozoan skeletons (Fig. 4a-b). However, there were also layers of denser and less dense bryozoans (Fig. 4b); the banding appears regular, suggesting an annual cycle but future studies will need to use isotope data to confirm or refute this assumption. The high pore space is consistent with the way dried bryostromatolites floated in the lab. The bryozoan itself seems to show banding with alternations of denser and less dense layers; the reason for this is unknown.

Porosity was extremely high. Furthermore, it is original. Observed bivalves did not bore into the bryozoans but are overgrown by the latter (Fig. 5a). Visual inspection shows that porosity varied somewhat randomly throughout the bryostromatolite, with some portions being more filled with mud than others (Fig. 5a), but porosity is always relatively high. This porosity is mostly connected, providing a habitat to the polychaetes and arthropods which inhabit the sample.

The microbes had a thrombolytic structure with clots connected by strands dominating the texture (Fig. 5b). These strands held the bryozoan layers and other components together, even gluing residue from hydrogen peroxide treatments together into mats (Fig. 5d) that were similar to those on actual bryostromatolites (Fig. 5c) albeit lacking cements. The strands may have been predominantly three dimensional but flattened by the vacuum used in gold coating/SEM imaging as rare cylindrical portions were observed. One microbial strand could both overgrow cements and be overgrown by them (Fig. 5e), suggesting that microbes and cements formed at the same time. Cyanobacteria are known to survive in anoxia and euxinia (Cohen et al. 1975), so the microbial layers are likely formed during anoxic times and were overgrown by bryozoans in more favourable conditions. 

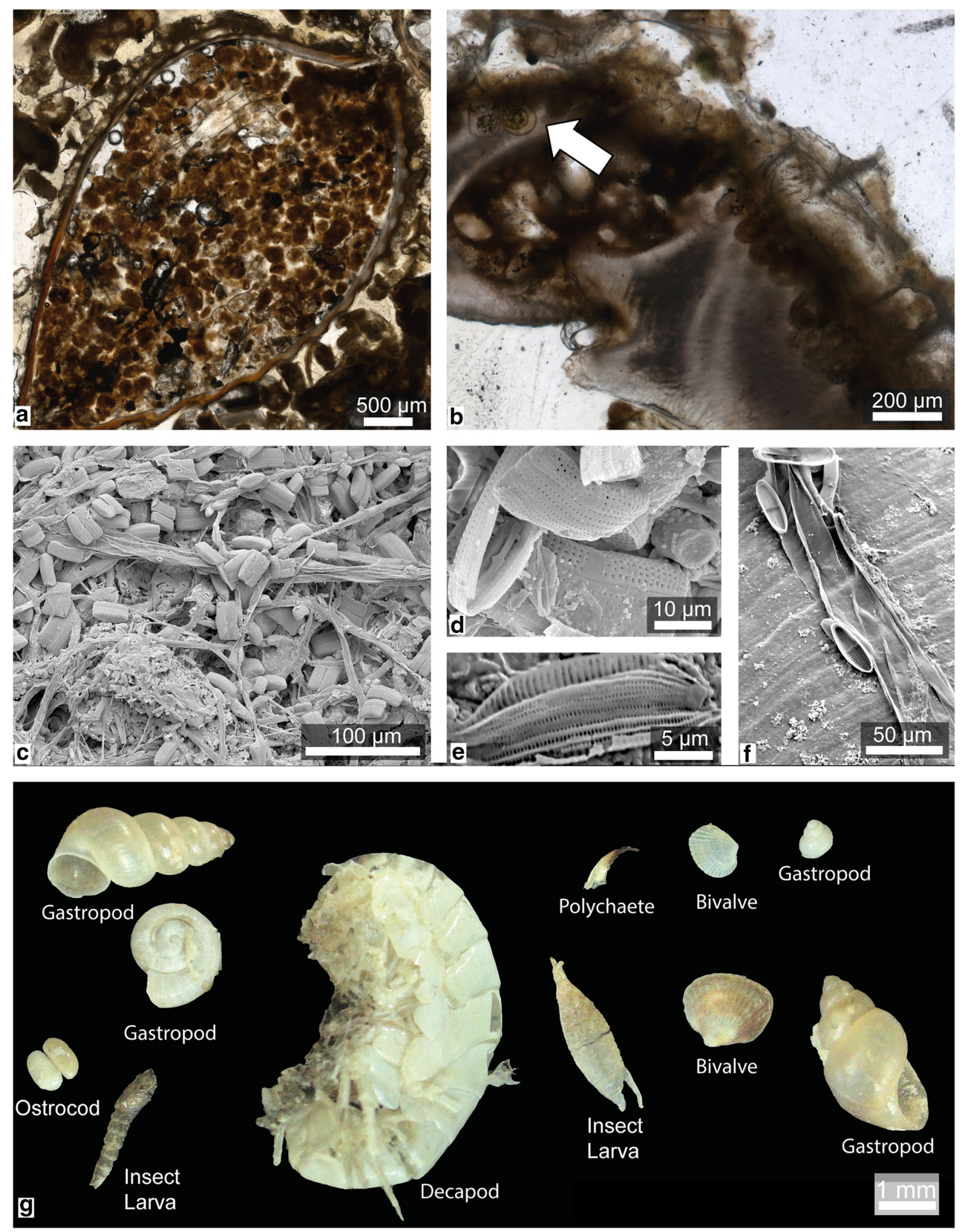

Fig. 6 Non-structure-forming taxa found in bryostromatolites. a Aphotic, peloid forming microbes that lived inside the articulated shells of dead bivalves. b Boring microbes found in bivalve shells (arrow). c A diatom meadow of Halamphora sp. 1. d pillow-shaped Halamphora sp. 1. e
Winged Halamphora sp. 2. has distinct fringes. f Capsule-shaped diatom identified as Achnanthes pseudogroenlandica? g Figure showing a sample of macrofauna diversity including bivalves, gastropods, ostracods, insect larvae, and a polychaete jaw 
Table 2 Values for salinity and ion concentrations in our study sites that far exceeded those in normal settings as defined by Algeo et al. (2015) ${ }^{1}$, Rainbow $(2018)^{2}$, and Orians et al. (1990) ${ }^{3}$

\begin{tabular}{llllll}
\hline Sample ID & Salinity & Sulphate & As & Mn & Ti \\
\hline Units & {$[\mathrm{ms} / \mathrm{cm}]$} & {$[\mathrm{mg} / \mathrm{l}]$} & {$[\mu \mathrm{g} / \mathrm{l}]$} & {$[\mu \mathrm{g} / \mathrm{l}]$} & {$[\mu \mathrm{g} / \mathrm{l}]$} \\
Ronde Weel & 21.32 & 950 & 9.2 & 250 & 370 \\
Kaaskenswater & 18.53 & 1300 & 3.3 & 78.5 & 180 \\
"Normal value" & 42.9 & $275^{1}$ & $0-1.5^{2}$ & $3-130^{2}$ & $<0.2^{3}$ \\
\hline
\end{tabular}

While bryozoans can survive microbial fouling (Todd and Turner 1988; Gerdes et al. 2005; Kaselowsky et al. 2005), all bryozoans found under microbial mats in these samples were also filled with cements (Fig. 5c) and thus presumed dead at the time of collection. This suggests that either bryozoans responded to microbial fouling with the tactic Scholz and Krumbein (1996) termed "surrender" or that regular environmental shifts terminated bryozoan growth, allowing thick microbial mats to develop. The complex, cauliflower-like morphology of the bryozoans and their layered morphology suggest that they were forming S-nodules (Scholz and Krumbein 1996) and thus using an "aggressive tactic" (Scholz and Krumbein 1996), which would rule out fouling as the cause of bryozoan death and support the hypothesis that environmental conditions such as periodic euxinia caused the bryozoans to die and microbial mats to flourish. This contradicts Kaselowsky et al.'s (2005) assertion that bryostromatolites are a separate category from Scholz and Krumbein's (1996) schema. Giant buds were not observed on our specimens, meaning that they did not exhibit m-laminae (Kaselowsky et al. 2005) and thus do not fit his definitions. A monitoring program over the course of a year would be needed to determine this.

\section{Diversity}

Diversity was relatively low with only 12 eukaryotic species present. The only bryozoan taxon has marine to brackish preferences (Nikulina 2007). Furthermore, the diatoms were all from genera that occupy a large habitat range; the only identified species is typically marine (Hartley 1986). This is unsurprising since the water was brackish and there were no obvious freshwater sources. The differences in salinity between Ronde Weel and Kaaskenswater despite being connected might indicate that they experienced shifting salinities from tidal influence; the Ronde Weel water samples were taken several hours before the Kaaskenswater samples, giving ample time for the tides to change. Furthermore, the taxa experienced heavy metal poisoning and euxinia, which exerts further limitations on which taxa could thrive in that environment. Over half of the taxa had easily fossilizable hard parts, giving us confidence in palaeontological diversity estimates of bryostromatolites.

\section{Conclusions}

Observations of microbial layers and cementation practices support the initial hypothesis that an alternation of bryozoanfavouring conditions and microbe-favouring conditions is essential to forming bryostromatolites. The cauliflower morphology of the bryostromatolites was formed by S-nodules similar to those seen by Scholz and Krumbein (1996), suggesting that microbial overgrowth was not the cause of the bryozoan's death. Therefore, oxygenated conditions are thought to have favoured bryozoans while euxinia is hypothesized to have killed the bryozoans and thus favoured microbial mats. Further monitoring is needed to test this hypothesis. Water tests confirmed the uniqueness of the water chemistry in this environment, suggesting that the marginal circumstances were key to the community's survival. The brackish environment would be stressful for most freshwater and marine life, arsenic and titanium are deleterious to most DNA-based life, and periodic euxinia is hypothesized from the high sulphate content; these factors excluded most life from the ponds, allowing these unique reefs to thrive.

Supplementary Information The online version contains supplementary material available at https://doi.org/10.1007/s12549-021-00490-3.

Acknowledgements We would like to thank Birgit Leipner-Mata provided her irreplaceable knowledge to making thin sections. Bryan Shirley lent the senior author necessary advice and training using the SEM. Inga Köhler assisted with algae identification and Andrzej Witkowski helped with the diatom identifications. Additionally, we thank Constantin Feuerabendt for his assisting work as student helper during the sample collection in the Netherlands. Additional thanks to Andrej Ernst and the anonymous reviewer for their insightful comments and additional citations which were helpful for this paper and will prove useful for future works. We also thank Peter Königshof for his editorial works.

Funding Open Acces funding enabled and organized by Projekt DEAL. Funding was provided by Friedrich Alexander University per funding agreements pertaining to master's students.

Data availability Material is stored by Friedrich Alexander University.

\section{Declarations}

Conflict of interest The authors declare no competing interests.

Open Access This article is licensed under a Creative Commons Attribution 4.0 International License, which permits use, sharing, adaptation, distribution and reproduction in any medium or format, as long as you give appropriate credit to the original author(s) and the source, provide a link to the Creative Commons licence, and indicate if changes were 
made. The images or other third party material in this article are included in the article's Creative Commons licence, unless indicated otherwise in a credit line to the material. If material is not included in the article's Creative Commons licence and your intended use is not permitted by statutory regulation or exceeds the permitted use, you will need to obtain permission directly from the copyright holder. To view a copy of this licence, visit http://creativecommons.org/licenses/by/4.0/.

\section{References}

Algeo, T. J., Luo, G. M., Song, H. Y., Lyons, T. W., \& Canfield, D. E. (2015). Reconstruction of secular variation in seawater sulfate concentrations. Biogeosciences, 12(7), 2131-2151. https://doi.org/10. 5194/bg-12-2131-2015.

Andruleit, H., Freiwald, A., \& Schäfer, P. (1996). Bioclastic carbonate sediments on the southwestern Svalbard shelf. Marine Geology, 134, 163-182. https://doi.org/10.1016/0025-3227(96)00044-8.

Bader, B. (2001). Modern bryomol-sediments in a cool-water, highenergy setting: The inner shelf off Northern Brittany. Facies, 44, 81-104. https://doi.org/10.1007/bf02668169.

Bijma, J., \& Boekschoten, G.J. (1985). Recent bryozoan reefs and stromatolite development in brackish inland lakes, SW Netherlands. Senckenbergiana maritima, 17, 163-185.

Bone, Y., \& James, N. P. (1993). Bryozoans as carbonate sediment producers on the cool-water Lacepede Shelf, southern Australia. Sedimentary Geology, 86, 247-271. https://doi.org/10.1016/00370738(93)90025-Z.

Burns, B. P., Goh, F., Allen, M., \& Neilan, B. A. (2004). Microbial diversity of extant stromatolites in the hypersaline marine environment of Shark Bay, Australia. Environmental Microbiology, 6, 1096-1101. https://doi.org/10.1111/j.1462-2920.2004.00651.x.

Chafetz, H.S., \& Buczynski, C. (1992). Bacterially induced lithification of microbial mats. Palaios, 7, 277-293. https://doi.org/10.2307/3514973

Clarke, J. D. A., Bone, Y., \& James, N. P. (1996). Cool-water carbonates in an Eocene palaeoestuary, Norseman Formation, Western Australia. Sedimentary Geology, 101, 213-226. https://doi.org/10. 1016/0037-0738(95)00066-6.

Claussen, A.L, Munnecke, A., \& Ernst, A. (2022) Bryozoan-rich stromatolites (bryostromatolites) from the Silurian of Gotland and their relation to climate-related perturbations of the global carbon cycle. Sedimentology. https://doi.org/10.1111/sed.12863

Cohen, Y., Jørgensen, B. B., Padan, E., \& Shilo, M. (1975). Sulphidedependent anoxygenic photosynthesis in the cyanobacterium Oscillatoria limnetica. Nature, 257(5526), 489-492. https://doi. org/10.1038/257489a0.

Costello, M.J., Emblow, C., \& White, R.J. (Eds.) (2001). European register of marine species. A check-list of the marine species in Europe and a bibliography of guides to their identification. Patrimoines naturels, 50, Paris. $463 \mathrm{pp}$

Ernst, A. (2019). Fossil record and evolution of Bryozoa. In A. SchmidtRhaesa (Ed.), Handbook of Zoology Online (pp. 1-24). Berlin: De Gruyter.

Ernst, A., Munnecke, A., \& Oswald, I. (2015). Exceptional bryozoan assemblage of a microbial-dominated reef from the early Wenlock of Gotland, Sweden. GFF, 137(2), 102-125. https://doi.org/10. 1080/11035897.2014.997543.

Gerdes, G., Kadagies, N., Kaselowsky, J., Lauer, A., \& Scholz, J. (2005). Bryozoans and microbial communities of cool-temperate to subtropical latitudes - Paleoecological implications. Facies, 50(3-4), 363389. https://doi.org/10.1007/s10347-004-0037-2.

Goncharova, I. A., \& Rostovtseva, Y. V. (2009). Evolution of organogenic carbonate buildups in the Middle through Late Miocene of the Euxine-Caspian Basin (Eastern Paratethys).
Paleontological Journal, 43(8), 866-876. https://doi.org/10.1134/ s0031030109080048.

Hartley, B. (1986). A check-list of the freshwater, brackish and marine diatoms of the British Isles and adjoining coastal waters. Journal of the Marine Biological Association of the United Kingdom, 66(3), 531-610. https://doi.org/10.1017/S0025315400042235.

Hayward, P.J. (1979). Deep water Bryozoa from the coasts of Spain and Portugal. Cahiers de Biologie Marine, 20, 59-75.

Hofmann, H.J. (2000). Archean stromatolites as microbial archives. In: R. Riding \& S.M. Awramik (Eds.), Microbial Sediments (pp. 315327). Springer: Berlin Heidelberg. https://doi.org/10.1007/978-3662-04036-2 34.

International Organization for Standardization. (2018). Water quality Sampling - Part 3: Preservation and handling of water samples (ISO Standard No. 5667-3:2018). Retrieved from https://www.iso. org/obp/ui/\#iso:std:iso:5667:-3:ed-5:v1:en

Kaselowsky, J., Scholz, J., Mawatari, S.F., Probert, P.K., Gerdes, G., Kadagies, N., \& Hillmer, G. (2005). Bryozoans and microbial communities of cool-temperate to subtropical latitudes - paleoecological implications. Facies, 50, 349-361. https://doi.org/10.1007/s10347004-0034-5.

Komárek, J., \& Anagnostidis, K. (Eds.) (2005). Cyanoprocaryota, 2. Teil: Oscillatoriales. Süßwasserflora von Mitteleuropa, (19/2, pp. 1 - 759). Elsevier Spektrum Akademischer Verlag Heidelberg, Germany.

Kröger, B., Desrochers, A., \& Ernst, A. (2017). The reengineering of reef habitats during the great Ordovician biodiversification event. Palaios, 32(9), 584-599. https://doi.org/10.2110/palo.2017.017.

McKenzie, L. A., Brooks, R. C., \& Johnston, E. L. (2012a). A widespread contaminant enhances invasion success of a marine invader. Journal of Applied Ecology, 49(4), 767-773. https://doi.org/10.1111/j.13652664.2012.02158.x.

McKenzie, L. A., Johnston, E. L., \& Brooks, R. (2012b). Using clones and copper to resolve the genetic architecture of metal tolerance in a marine invader. Ecology and Evolution, 2(6), 1319-1329. https:// doi.org/10.1002/ece3.241.

Merz, M. U. E. (1992). The biology of carbonate precipitation by cyanobacteria. Facies, 26(1), 81-101. https://doi.org/10.1007/ BF02539795.

Moissette, P., Cornee, J.-J., \& Koskeridou, E. (2010). Pleistocene rolling stones or large bryozoan nodules in a mixed siliciclastic-carbonate environment (Rhodes, Greece). Palaios, 25, 24-39. https://doi.org/ 10.2110/palo.2009.p09-024r.

Monumentenstad, Z. (2018). Dossier: de ronde Weel. ZierikzeeMonumentenstad, Kingdom of the Netherlands. Retrieved May 15, 2019 from https://www.zierikzee-monumentenstad.nl/ dossier-ronde-weel

Moran, D. T., Dias, G. M., \& Marshall, D. J. (2010). Associated costs and benefits of a defended phenotype across multiple environments. Functional Ecology, 24(6), 1299-1305. https://doi.org/10.1111/j. 1365-2435.2010.01741.x.

Nikulina, E.A. (2007). Einhornia, a new genus for electrids formerly classified as the Electra crustulenta species group (Bryozoa, Cheilostomata). Schriften des Naturwissenschaftlichen Vereins für Schleswig-Holstein, 69, 29-40.

Orians, K. J., Boyle, E. A., \& Bruland, K. W. (1990). Dissolved titanium in the open ocean. Nature, 348(6299), 322-325. https://doi.org/10. $1038 / 348322 \mathrm{a} 0$

Palinska, K. A., Scholz, J., Sterflinger, K., Gerdes, G., \& Bone, Y. (1999). Microbial mats associated with bryozoans (Coorong Lagoon, South Australia). Facies, 49(41), 1-14. https://doi.org/10.1007/ bf02537456.

Pantazidou, A., Louvrou, I., \& Economou-Amilli, A. (2006). Euendolithic shell-boring cyanobacteria and chlorophytes from the saline lagoon Ahivadolimni on Milos Island, Greece. European Journal of Phycology, 41(2), 189-200. https://doi.org/10.1080/ 09670260600649420. 
Piola, R. F., \& Johnston, E. L. (2006). Differential tolerance to metals among populations of the introduced bryozoan Bugula neritina. Marine Biology, 148(5), 997-1010. https://doi.org/10.1007/ s00227-005-0156-5.

Proemse, B. C., Eberhard, R. S., Sharples, C., Bowman, J. P., Richards, K., Comfort, M., \& Barmuta, L. A. (2017). Stromatolites on the rise in peat-bound karstic wetlands. Scientific Reports, 7(15384). https:// doi.org/10.1038/s41598-017-15507-1.

Rainbow, P. S. (2018). Estuaries. In P. S. Rainbow (Ed.), Trace metals in the environment and living organisms: The British Isles as a case study (pp. 401-564). Cambridge: Cambridge University Press. https://doi.org/10.1017/9781108658423.007.

Rosso, A., Di Geronimo, I. (1998). Deep-sea Pleistocene bryozoa of southern Italy. Geobios, 31, 303-317.

Saint Martin, J.P., \& Pestrea, S. (1999). Les constructions à serpules et microbialites du Sarmatien de Moldavie. Acta Palaeontologica Romaniae, 2, 463-469.

Saint Martin, J.P., \& Saint Martin, S. (2015). Calcareous microbialites and associated biota in the Mediterranean coastal lagoons and ponds of southern France: A key for ancient bioconstructions? Geo-EcoMarina, 21, 55-71.

Scholz, J., \& Krumbein, W.E. (1996). Microbial mats and biofilms associated with bryozoans. In D.P. Gordon, A.M. Smith, \& J.A. GrantMackie (Eds.), Bryozoans in space and time (pp. 283-298). NIWA Ldt, Wellington.

Shelton, L.R. (1994). Field guide for collecting and processing streamwater samples for the National Water-Quality Assessment Program. USGS Open-File Report, 94-455, 1-42.
Shestakov, S.V., \& Karbysheva, E.A. (2017). The origin and evolution of cyanobacteria. Biology Bulletin Reviews, 7 (4), 259-272.

Sladkovskaya, M. G. (2017). Trochidae (Gastropoda) from the Sarmatian Basin of the eastern Paratethys. Paleontological Journal, 51(14), 1453-1583. https://doi.org/10.1134/s0031030117140039.

Stal, L.J. (2012). Cyanobacterial mats and stromatolites. In B. A. Whitton (Ed.), Ecology of Cyanobacteria II: Their Diversity in Space and Time. Springer Dordrecht Heidelberg New York London, p. 65125. https://doi.org/10.1007/978-94-007-3855-3_4.

Stanier, R.Y., \& Cohen-Bazire, G. (1977). Phototrophic prokaryotes: the cyanobacteria. Annual Review of Microbiology, 31, 225-274.

Tâmega, F.T. de S., Spotorno-Oliveira, P., Dentzien-Dias, P., Buchmann, F.S., Vieira, L.M., Macario, K., Nash, M., Guimarães, R.B., Francischini, H., \& Bassi, D. (2019). Palaeoenvironmental dynamics of Holocene shoreface bryoliths from the southern coast of Brazil. The Holocene, 29, 662-675. https://doi.org/10.1177/ 0959683618824739.

Taylor, P.D., \& Ernst, A. (2004). Bryozoans. In B.D. Webby, F. Paris, M.L. Droser, \& I.G. Percival (Eds.), The Great Ordovician biodiversification event (pp. 147-156). New York: Columbia University Press.

Todd, C.D., \& Turner, S.J. (1988). Ecology of intertidal and sublittoral cryptic epifaunal assemblages. II. Nonlethal overgrowth of encrusting bryozoans by colonial ascidians. Journal of Experimental Marine Biology and Ecology, 115, 113-126.

Publisher's note Springer Nature remains neutral with regard to jurisdictional claims in published maps and institutional affiliations. 